\title{
Rahvaluule e-kursused: uudishimust kogemuseni
}

Tiiu Jaago

Teesid: Artiklis tutvustatakse WebCT õpikeskkonna kasutust Tartu Ülikooli rahvaluuleainete õpetamisel aastatel 2000-2007. Keskendutakse autori kogemustele, mis rajanevad WebCT-kursustest osavõtul õppijana, kursuste loomisel ja läbiviimisel. Võrreldakse suhtumist erinevatesse õpikeskkondadesse (auditoorne ja veebipõhine kursus). Erinevate töökeskkondade kasutamine tähendab autori järeldusel võimaluste avardumist, mitte olemasolevate (klassikaliste õpikeskkondade ja õpetamismeetodite) väljavahetamist.

Märksõnad: E-õpe, interaktiivne õpikeskkond, kõrgkoolipedagoogika, rahvaluule õpetamise metoodika, WebCT

Rahvaluule e-õppe kursusi Tartu Ülikoolis on kolme laadi: esmalt vaba juurdepääsuga õppematerjalide e-publikatsioonid (aine koduleheküljed, e-loengud ja -õpikud); ${ }^{1}$ teiseks piiratud juurdepääsuõigusega interaktiivsed e-õppekeskkonnad (nn WebCT-kursused²) ja kolmandaks videoloengud (CD või DVD). Artiklis keskendun WebCT-kursustele, täpsemalt kogemustele, mida olen omandanud nende kursuste väljatöötamisel ja läbiviimisel.

\section{Mis on WebCT ja milline on tema koht 2000. aastate õppejõu argielus}

WebCT tähendab veebipõhist interaktiivset õpikeskkonda, mille kursus sisaldab esmalt õppematerjale (õppetekstid, näited, harjutused, hindelised ülesanded), teiseks õppimise lisavahendeid (õpieesmärkide sõnastused, materjalide väljatrüki võimalus, lingid lisamaterjalidele, kalender), kolmandaks ainult õppijale endale nähtavaid lehekülgi (oma failide ja märkmete kogu, isiklik kalender, tulemuste arvestus). Haridustehnoloogide sõnutsi ei tähenda tänapäevane veebipõhine õpe pelgalt materjalide netti ülespanemist, et õppijad need 
iseseisvalt läbi töötaksid, vaid see eeldab uut lähenemist õppimisele: st tõepoolest raskuskeskme nihkumist õpetamiselt õppimisele (Pilt \& Läheb 2005: 346). Seega saab iga WebCT-kursus oma näo õppejõu, haridustehnoloogi ja õppijate koostöös.

Kursuste loomist alustasin koos Tartu Ülikooli haridustehnoloogi Lehti Pildiga, hiljem olen töötanud Marju Piiriga, kuid mida enam õppisin ise tundma kursuse loomise tehnilist külge, seda enam olen eelistanud ise tegeleda ka sellega, kasutades haridustehnoloogide nõuandeid, eriti küsimuste tekkimisel ja probleemide lahendamisel. Kursused, mille loomisel olen osalenud on:

- Sissejuhatus eesti rahvaluulesse ja folkloristikasse (tehniline lahendus Lehti Pilt), 2000, täiendatud 2004,

- Dialoog privaatse ja avaliku elu vahel, koostöös Eesti Kirjandusmuuseumi uurijate Mare Kõiva ja Liisa Vesikuga, 2002; selle täiendatud ingliskeelne versioon 2003 (tehniline lahendus Lehti Pilt),

- Eesti rahvaluule (tehniline lahendus Lehti Pilt), 2004,

- Folkloristika alused, 2005,

- Regilaulu uurimise meetodid, $2005,{ }^{3}$

- Teksti- ja kontekstikesksed meetodid folkloristikas, $2006,{ }^{4}$

- Bakalaureusetöö (rahvaluule), 2006,

- Rahvaluule õpetamise võimalusi koolis, koostöös Risto Järve ja Merili Metsvahiga, 2007.

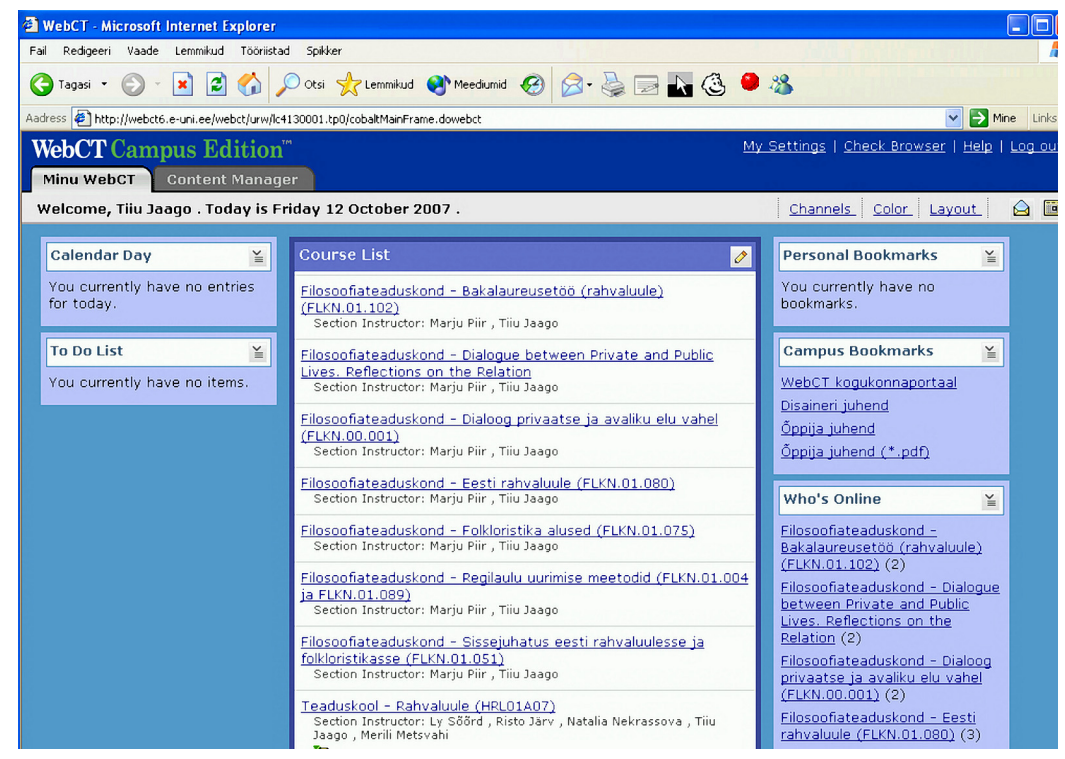

Joonis 1. MinuWebCT-lehekülg - kursuste loend. 
Õppijana olen osalenud nii e-õpet käsitleval kõrgkoolipedagoogika-kursusel (Turu ülikooli juures kureeritud "Course Design", 2003-2004) kui ka WebCT tehnika poolt tutvustavatel koolitustel ("Kaugkoolituskursuse organiseerimine WebCT vahenditega", 2005, e-õppepäevad ehk nn e-lõunad 2006). Aastatel 2003-2005 osalesin innukalt e-õppe konverentsidel ja võtsin prooviks ka ühe keelekursuse ("Saksa keele grammatika kursus" 2006), et näha seestpoolt WebCT-kursuse võimalusi, eriti aga tunnetada õppija-vaadet. Seega langeb minu aktiivsem huvi WebCT-kursuste vastu aastatesse 2003-2006. See periood sisaldab kvalitatiivset muutust minu igapäevatöös, kuna hakkasin tajuma loengute, seminaride ja iseseisva töö kõrval uusi võimalusi, kusjuures sain rakendada senisest enam probleemõpet ${ }^{5}$ ja rühmatööd. Saavutasin ka oskused kursust ise tehniliselt kujundada, mis muutis mu töö paindlikumaks: tundes WebCT kui õpikeskkonna tehnikat, sain ülesandeid koostada just WebCT võimalusi arvestades. Kuid sellesse perioodi jääb ka pettumus, mis seostub peamiselt ülekoormusega. Tehnika täiustamine viis WebCT uue versiooni kasutuselevõtuni 2006. aastal ja see tõi kaasa vajaduse viia olemasolevad kursused vanast versioonist üle uude. Ühelt poolt tähendas see WebCT uue versiooni tehnika tundmaõppimist, kuid sellele lisaks ka ülemäärast tööd olemasolevate kursuste seadistamisel uues versioonis. Selline töö tapab õppejõu, sest tehnika ei ole enam vahend, vaid eesmärk omaette. Siiani ei ole ma päriselt selgusele jõudnud WebCT uue versiooni eelistes vana ees. On tõsi, et kursuse haldamine uues versioonis on tunduvalt käepärasem kui vanas. Seevastu õppijale näikse uus versioon olevat keeruline ja ekraanilt vastuvaatav pilt nii kirju, et selles orienteerumine võtab liiga palju aega, nii et aineni jõutakse õieti siis, kui osa kursusest juba läbi. Ka on vastuvõetamatu, et uut versiooni tuleb kasutada ingliskeelsena (st osa kursuse tekstist, mille WebCT ette määrab, on ingliskeelne, see, mida ise täidan, eestikeelne) - segakeelsus on aga häiriv (kui just mitte arusaamatusi tekitav, siis kultuuriliselt nõme igal juhul).

Kui alustasin oma esimese kursusega 2000. aastal Lehti Pildi juures (tema, mitte enda initsiatiivil, muide!), oli mind käivitavaks jõuks uudishimu. Praeguseks on WebCT-kursuste koostamine ja kasutamine õppetöös saanud osaks argipäevast, ilma milleta ma oma tööd õppejõuna ette ei kujuta. Jätkan aga uudishimulikult uute võimaluste lisamist kursustele (sünkroonsed audioloengud materjali esitamisel, kaasõppijate ja enda hindamine kui ühe õpivõimaluse rakendamine) ja võtan jätkuvalt vastu õppetehnoloogiaid arendavaid ettepanekuid (viimati näiteks koostöö Eesti e-Ülikooli peaharidustehnoloogi Karin Ruuliga, kellega koostame iseseisvaks õppimiseks sobivat materjali tegelemiseks suguvõsa ajalooga). 


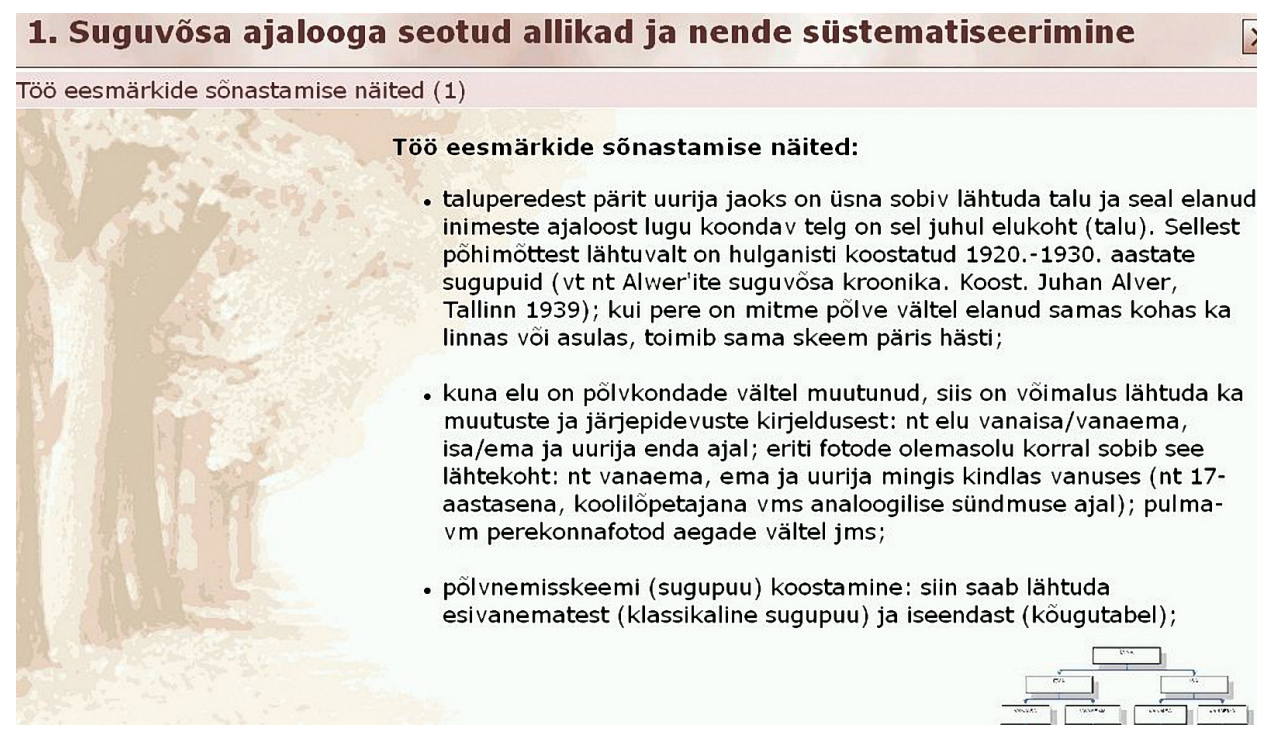

Joonis 2. Lehekülg iseseisvaks õppimiseks: materjal Tiiu Jaagolt, tehniline lahendus Karin Ruulilt.

WebCT-kursuste loomisele ajendasid arengud rahvaluuleteaduses 1990. aastate teisel poolel. Esmalt Eesti Kirjandusmuuseumi folkloristikalehekülje kujunemine ja e-väljaannete rohkus, mis ärgitas mõtlema, kuidas muuta seda materjali õppijatele käepäraseks. Teiseks asjaolu, et rahvaluule ise, olles sünkreetiline, sobib veebiesitluseks: kursuse näitematerjalide hulka on võimalik lisada nii heli-, video- kui ka pildifaile (nt arhiivi käsikirjadest vms), mis jäävad auditooriumis ilma tehnika abita kättesaamatuks. Kolmandaks muutused kõrgkoolielus, st nii üliõpilaste elustiili muutumist massiülikoolis kui ka õppekavade uuenemist (erialade integreeritud õppekavad, üliõpilaste liikuvus õppekavast teise jms). Tänapäevased õppekavad ei rajane eriala läbimisel asteastmelt. Nii võib juhtuda, et näiteks regilaulu-uurimise erikursusele võivad sattuda kokku rahvaluulet õppinud tudengid kõrvuti nendega, kellel puudub baasharidus selles vallas. Veebikursus võimaldab tasandada lünki, sest ma saan materjali struktureerida tasanditeks ja neid siis omavahel linkidega siduda. Loengul tuleb aga teha üks valik, sest ühel ja samal ajal ei saa esitada materjali erinevatele tasemetele.

Veebikursuste loomisel olen lähtunud probleemõppe põhimõtetest, kus õppematerjalid toetavad ülesannete lahendamist. Teadmiste kontroll (hindamine) ei rajane vahetult õppeteksti tundmisel, vaid omandatud teadmiste rakendamisel teemakohaste praktiliste ülesannete lahendamisel. (Siiski on õppijal endal võimalus enesetestide abil kontrollida seda, kuidas ta loetud tekstist aru 
sai ja mil määral on see vastavuses õppejõu ootustega.) Hindelised ülesanded on nii rühmale kui ka individuaalsed. Lõpphinne kujuneb kursuse vältel tehtud ülesannete eest saadud punktide summa põhjal.

\section{Milliseid (eel)arvamusi on loonud WebCT}

WebCT-kursuste koostajate põhiprobleemid (peale kursuse koostamist ja läbiviimist puudutavate teemade) on olnud seotud õppejõudude koormuse arvestusega ja kursuse materjalide autorikaitsega. Kellel aga puuduvad kogemused WebCT-kursustest, neid olen kuulnud kahtlevat, kas õppejõu osa veebivahendusel liiga väike ei ole või puudub see ehk üldse. See asjaolu õigustab nende arvates auditoorse töö eelistamist veebi vahendusel õpetamisele/õppimisele. Teine eelarvamus seostub ettekujutusega, et masin teeb õppejõu töö hästi lihtsaks, nii et õppejõud tööd tegema ei peagi: masin ise kontrollib õpilase töö üle ja hindab. Võimalik, et WebCT-kursus on tehtav nii, et see tunduks masina ja õppija koostööna, aga ma ei ole ise midagi sellist kohanud. Ka ei näe ma veebikursustes auditoorse töö alternatiivi. Kõikidel õpetamis- ja õppimiskeskkondadel on omad võimalused ja eripärad. Need ei moodusta üksteise alternatiive, pigem on tegemist võimaluste mitmekesisusega. Enda kui õppejõu osalust ei välista ma loengutes ega ka WebCT kursustel. Õppijana tean, kui olulist rolli mängib kursusel õppejõu kohalolek, eriti see, kas, millal ja kuidas ta tagasisidet annab. Hoopis teine olukord on õppida iseseisvalt töölehtede abil (mitte-interaktiivses keskkonnas, näiteks Heiki Koovi koostatud PowerPointi e-koolitus aadressil http://www.koov.ee või regulaarselt ilmuvas E-õppe uudiskirjades avaldatud töölehed aadressil http://portaal.e-uni.ee/uudiskiri). Töölehtedelt ootan ma täpseid juhiseid, sammhaaval liikumist eesmärgi suunas. WebCT-kursustel on aga oluline teemaarutelu, sh tagasiside.

Ôppijate tagasisidest olen aru saanud, et on neid, kellele veebi kaudu suhtlemine väga sobib (ja see ei ole seotud ainult suurte vahemaade tagant õppimisega vaid ka õppijate eripäraga). Aga on ka neid, kellele see lihtsalt ei sobi. Kuna õppejõuna korraldan nii loenguid-seminare kui ka veebikursusi, olen märganud, et esimest peetakse siiski traditsiooniliseks ja loomulikuks, teist nagu pisut alternatiivseks. Milles see ilmneb? Näiteks Tartu Ülikooli õppeinfosüsteemis (ÕIS) saan õppijatelt regulaarselt tagasisidet. Hinnang Ei meeldinud WebCT, kohutavalt tü̈̈tu, loengud oleks paremad olnud ei ole sugugi haruldane. Samas ei ole ma saanud ÕIS-is, selles ametlikus hindamiskeskkonnas, soovitust korraldada loengute asemel veebikursus. Kui aga üliõpilastega suhelda väljaspool ametlikku hindamiskeskkonda, on loengute vastu protesteerijaid (stiilis, et see või teine aeg ei sobi kas tunniplaanide kattumise või 
töölkäimise tõttu) häirivalt palju. Seega ei tajuta päriselt veel erinevate õppekeskkondade olemasolu, iseseisvust ja lõimumist üldisesse õppekeskkonda. Loengud on üldise arusaama järgi ülikooliomane (normaalne) õppekeskkond, muud keskkonnad aga veel mitte. Ise ei ole ma oma kursuste koostamisel alternatiivi-printsiibist kunagi lähtunud. Käsitan erinevaid keskkondi kui võimalusi oma töö paremaks korraldamiseks.

Järgnevalt on toodud mõned näited 2007. aasta kevadsemestril WebCT-kursustel osalenute arvamustest, mis esitati tagasiside küsitlusele kursusel (mitte ÕIS-is). Esmalt "Eesti rahvaluule" õppijate hinnangud. See 2004. aastal loodud 4 ainepunkti kursus koostati üliõpilastele, kes ei ole valinud rahvaluulet peaaineks (peamiselt etnoloogia-, aga ka filoloogia- ja semiootikaüliõpilastele) ${ }^{6}$ Kursus koosneb kolmest teemast (rahvaluule mõiste, rahvaluule aine, rahvaluule kultuuritervikus) ning ülesandest kirjutada töö rahvaluule ja oma eriala seotusest. Teemad sisaldavad nii õppetekste kui ka individuaalseid testja rühmatööna tehtavaid aruteluülesandeid. Tagasiside foorumil oli vaja hinnata enda kui õppija tööd ja kursusel avanenud võimalusi teemat omandada (millised eesmärgid õppija endale seadis, mil määral ta neid täitis; milliseid WebCT-kursuse võimalusi ta kasutas ja milliseid mitte - see küsimus on ajendatud asjaolust, et kursuse võimalused veebis on alati suuremad kui nõudmised, mis esitatakse õppijale kursuse edukaks läbimiseks). Kuna suur hulk tööd tehakse rühmaaruteluna, kirjeldati vältimatult ka kaasõppijatega koostöös omandatud kogemust. Ilmneb, et e-kursuse oluliseks plusspooleks on võimalus planeerida oma aega, kaasõppijate toetus ja koostöös kujundatud õhkkond foorumitel, õppejõu kiire tagasiside. Märkimisväärne on aga ka väide, et nii oma kui ka kaaslaste töö suhtes tunti suuremat vastutust kui suuliste esituste puhul. Ilmnevad ka eelarvamuste kokkukukkumised (kas rahvaluulet on tõesti võimalik õpetada veebis?!) või said need hoopis kinnitust (veebi kaudu suhtlemine on hirmutav).

Mulle meeldib olla oma aja peremees. See ongi WebCT kursus(t)e juures kõige positiivsem - sa võid võtta brauseri lahti siis, kui sa parasjagu aine vastu huvi tunned. Tähtajad tähtaegadeks - need distsiplineerivad. Neid on vaja, muidu unustaks kõik asjad ära. Nagu eelnevaski punktis mainitud - täpselt mulle sobiv kursus. Õhkkond oli tore. Mis mulle eriti meeldis, oli see, et õppejõud võttis nii rühma- kui üldistel foorumitel arutelust osa ning tegeles igaühega ka individuaalselt. Erinevalt tavalistest suurtest loengutest paneb see sind palju enam oma tööd hindama. Ja ka teiste oma, mingil põhjusel.

Mulle meeldis õppejõu poolne kiire reageerimine küsimuste ja probleemide korral ning väga hea, et iga teema lõpus oli ka juhendajalt tagasiside, 
kommentaarid jms. Minu meelest on see õppetöö puhul üks suurimaid miinuseid, kui ôpilased ei saa tagasisidet.

Kursus oli teemakohane, pungil igasugu põnevast infost, mitmekesine, rühmatöö oskust treeniv (väga vajalik oskus!), silmaringi ja teadmistepagasit avardav.

Poleks ealeski osanud aimata, et rahvaluule ainet võiks neti teel õpetada, aga ennääe!

Alguses suhtusin ma äärmiselt skeptiliselt sellesse, et aine on WebCT keskne-tundus olevat utoopne mõte, et ma kõikide ülesannetega õigeagselt valmis saan. Hästi palju distsiplineeris iseennast. Tegelikult mulle lópuks siiski meeldis see, et ma ei pidanud iga nädal kindlal ajal kindlas kohas olema, vaid sain olla iseenda aja peremees.

Olen võib-olla vanamoodne, aga harjunud silmast silma suhtlema. Kõiksugused interneti foorumid on alati hirmutanud mind. Siin ma alguses üritasin olla ka aktiivne, aga lõpuks ikkagist ei osanud. Olen muidu rühmatöid teinud ja saanud hästi hakkama, aga interneti põhjal, kus inimesi ei tunne ega näe... see muutis minu jaoks raskeks. Võib öelda suisa, et foorumid on mu üks suurimaid foobiaid - kartusi.

Mulle meeldis lugeda teoreetilist materjali ja tore oli see, et need hindelised ülesanded, mis me tegema pidime ei olnud 100\% copy-paste sellest, mida me lugesime, st need ülesanded "sundisid" ise järeldusi tegema ja olid analü̈̈si oskust arendavad.

Kursus oli huvitav, polnud enne webct kasutanud. Rühm oli ka väga tore. Äitäh teile kõigile, kellega ma ühes rühmas olin!!!!

Võrdluseks on toodud 2007. aasta kevadsemestri õppijate arvamused kursuselt "Dialoog privaatse ja avaliku elu vahel" (loodud avatud ülikooli täienduskoolituse raames 2002. aastal). Erinevalt eeltoodud õppijatest on järgnevas tegemist ainult avatud ülikoolis õppijatega, seega kaugkoolitusel osalenutega (üksikuid kaugõppijaid on alati ka eelkirjeldatud kursusele tulnud). Samas aga oli sel aastal ühendatud kaks rühma: üks kirjanduse ja rahvaluule bakalaureuse tasemekoolitusest (nemad kohtuvad regulaarselt sessioonidel, kuna nad läbivad õppekava kõik kursused) ja teine täienduskoolitusest (kes valivad ülikooli kursuste pakkumise seast üksikuid ja seetõttu kaasõppijatega ei kohtu ega tunne ka üksteist). Dialoogi-kursus on üles ehitatud temaatiliste artiklite analüüsile (inimene ja koduloom, inimene ja emotsioonid, migratsioon, kodu, sünd ja surm). Kursuslased loevad iga teema kohta kaks artiklit ja tee- 
vad neist kavakohase kokkuvõtte aruteluks rühmatöö foorumil. Sellele lisaks kirjutavad õppijad oma kogemustest vastaval teemal, et arutleda kaasõppijatega oma seisukohtade ja arvamuste üle. Alljärgnevad tsitaadid on antud tagasisidena vastuseks küsimusele "Kuidas hindad kaasõppijatega jagatud kogemust?”. Neistki sõnavõttudest ilmneb, et kursuse valmispanemine õppejõu poolt on vaid üks osa kogu kursusest ja kursuse tegeliku hinguse loovad õppijad oma töö käigus.

Kursusekaaslastega jagatud kogemus andis mulle palju juurde. Suur pluss on asja juures see, et nad olid kõik võorad inimesed erinevate taustadega. Just selle pärast oli siin ka palju eriarvamusi ja aktiivne arutelu toimis hästi. Kasutegur oleks kindlasti väiksem olnud, kui ma oleks neid teemasid arutanud oma sõprusringkonnas.

Kogemus on väärt kogemus. Tihtipeale on inimese tutvusringkond üsna sarnane enda omaga ning sellest erinevate inimestega ei juhtu sellistel teemadel arutlema. Väga positiivne kogemus ning võimalus. Selliseid arutelusid võiks praktiseerida ka teistes valdkondades.

Kogemuste jagamine on alati rikastav ning siin esinesid teemad, mida tavalises seltskonnavestluses üles ei võeta. Alati on hea saada tuge oma arvamustele ning ka vaidlemine on (minu jaoks) väga meeli ergutav tegevus, andes võimaluse aina sügavamale endasse vaadata.

Mulle meeldis selline kirjalik arutelu kohutaval kombel, kuna reaalselt toimuvatel vestlustel on inimestel väga inetu komme üksteisele vahele rääkida ja see on minu jaoks alati väga häiriv - pigem ei võta siis üldse sõna. Huvitav oli. Päris ootasin, et õhtuti arvuti ligi saada.

See on nagu omamoodi teraapia, kui saad oma arvamust avaldada ja siis kuulda, mida teised sinu öeldust arvavad. Samas ka lugeda teiste mõtteid ja jälle oma arvamust avaldada. See on õpetlik ja arendav. See aitab iseennast paremini tundma õppida. Samuti avardab see pilti sellest, kui erinevaid inimesi olemas on. Ja kui keegi sinu seisukohast väga erinevale arvamusele jääb - ka see on õpetlik ja suunab sind oma mõtteid avardama.

Hindan teistega jagatud kogemust kõrgelt. Sain oma kursuse kaaslastest palju teada. Nemad said ka minust palju teada. Olime kõik üllatavalt avameelsed. Teistega, kellega tõenäoliselt kokku tavaelus ei puutu, oli samuti huvitav vestelda ja ennast nendega võrrelda. Kursuselt tuli välja, et paljud mõtlevad ja tegutsevad sarnaselt. See andis tuge, et teised ka mõtlevad teatud situatsioonides nii või tegutsevad just nii. Samas olime 
ka nii erinevad, ja see on nii huvitav. Pakkus lausa naudingut teiste arvamusi lugeda, eriti jah, kui need erinesid täiesti minu omadest. Üldjoontes aga olime siiski üllatavalt sarnased.

Tegelikult ei sobi mulle vist selline veebi teel arutlemine. ei tahaks nagu väga pikka aega kellegagi enam midagi ainult kirjutamise teel arutada. vahetu kontakt inimesega on pool arutlemise võlust. teemad olid muidugi huvitavad ja eriti südamelähedane on surma teema, kõik hingede ja elu mitmepoolsustega seonduv.

Tõeliselt huvitavad inimesed, kes viitsisid sõna võtta. Hästi soodne keskkond oma mõtete väljaütlemisteks, väga heatahtlik suhtumine kõigisse.

\section{Milliseid kogemusi on pakkunud kursuste koostamine}

Alustasin WebCT-kursuste loomist spetsialisti Lehti Pildi kõrval ja juhendamisel, jälgides tööetappe töö käigus. Kui aga Lehti Pilt oli mulle andnud esmase kogemuse, hakkas ta mind suunama kursustele, et omandaksin süsteemsemad teadmised sellest, mida e-kursuse ettevalmistamine tähendab. Kursuse sisulise poole ettevalmistamist nimetatakse kursuse õpidisainiks, mille käigus luuakse prototüüpkursus, mida seejärel hakatakse WebCT keskkonnas tehniliselt vormistama. "Eesti rahvaluule" kursuse õpidisain oligi mu õpingute sisuks "Course Design" kursusel 2003. aasta sügissemestril.

Õpidisain kui protsess koondab nii õppematerjale, õpetamisstrateegiate kui ka õpitegevuste kavandamist ja hindamispõhimõtete väljatöötamist. Kavandamiste käigus koostatakse õpieesmärgid ja juhendid õppijatele. Õpidisaini mudelitest tutvustatakse näiteks ADDIE-t (nimetuse iga täht tuleneb tegevusetapi ingliskeelsest nimest): analüüs (analyze), disain (design), arendus (develop), rakendus (implement), hindamine (evaluate) (vt lähemalt Pilt \& Läheb 2005: 348 jj). Selle protsessi käigus kujuneb üldiselt välja kursuse detailne kirjeldus. $^{7}$

Üks neist õpidisaini etappidest seostub kursuse kujunduselementide loomisega: päis, ikoonid värvi- ja graafiline lahendus. Minu silmis on see olnud väga oluline nii õppijana kui ka kujundajana - see loob keskkonna, kus on hea olla (või vastupidi). Kursuse loomise õppimise juures on alati olnud ülesandeks ka olemasolevate nn demokursuste analüüs. Märkasin üsna ruttu, et liiga kirju avapildiga kursusel ma ei orienteeru kuidagi. Oli kursusi (eriti Ameerika ülikoolide omad), kus avalehel oli palju informatsiooni õppejõu kohta (pilt, tervitussõnad või video, kutse tulla kursusele jm reklaamivaid tekste, mis kõik olid värvilised ja sageli ka liikuvad), teste õppijale (et kontrollida, kas 
tehnilised võimalused on käepärased) jms. Euroopa ülikoolide e-kursused olid enam suunatud ainele, mitte aine ümbrusele, ja see sobib mulle paremini. Oma kursuse avalehti kujundades suhtun kursusse kui raamatusse, millel on oma kujundus ja ühtlasi identiteet. Näiteks "Folkloristika aluste" kursuse kujunduses on kasutatud Fr. R. Kreutzwaldi teksti 1861. aasta raamatust Sipelgas, kus ta annab nime "vana vara" valdkonnale, mida tänapäeval tuntakse rahvaluulena. "Eesti rahvaluule" kursuse kujunduses on aga aluseks üks omaaegne kiri, mille õde mulle ülikooli ajal saatis. Kirja servale oli ta kritseldanud ja kleepinud motiivi, mis oli inspireeritud minu erialavalikust - rahvaluulest.

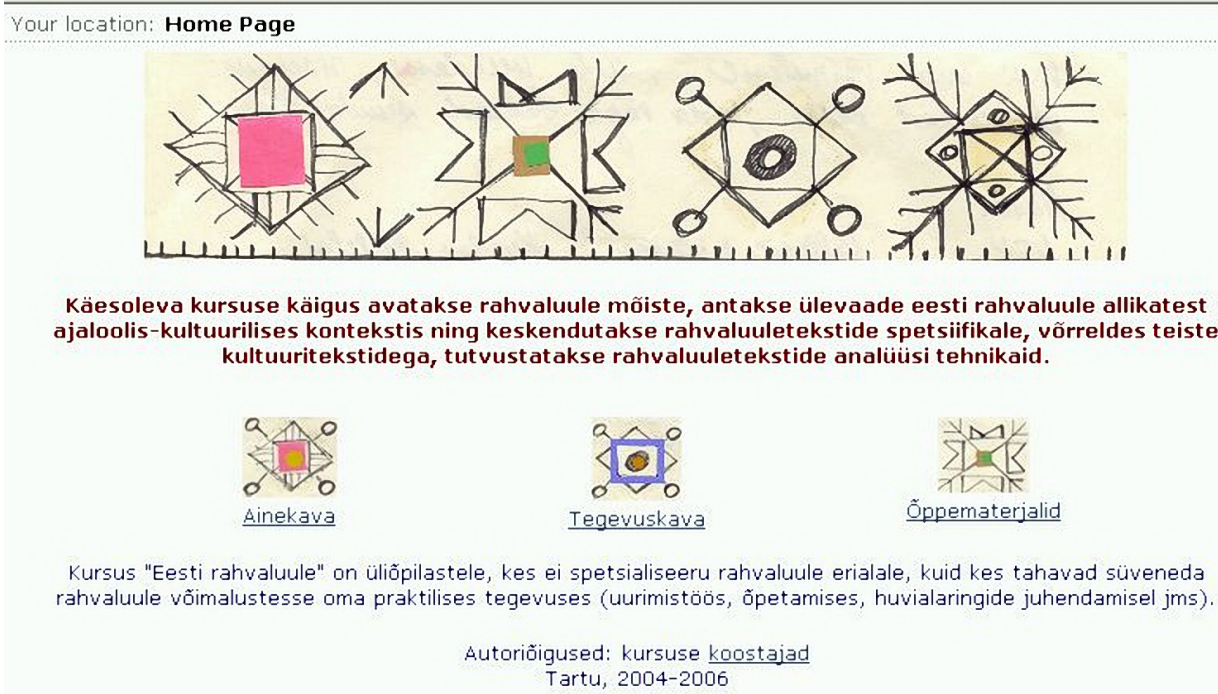

Joonis 3. Kursuse "Eesti rahvaluule" avaleht.

Iga kursuse erinev kujundus on minu meelest vajalik ka visuaalselt: ma tean, millisel kursusel ma hetkel olen. (WebCT pakub ka standardseid lahendusi, kuid kursuste loendist nähtub, et neid ei kasutata kuigi aktiivselt.) ${ }^{8}$

Uues WebCT versioonis on kolm “vaadet": kujundaja, õppejõu, õppija oma (vanas versioonis oli kaks vaadet: kujundaja ja õppejõu omad olid ühendatud). Vastavalt on jaotatud ka rollid kursusel: kujundaja - kursuse tehnilise poole looja, õppejõud - kursuse läbiviija, õppija - kursuse läbija (ka vaatleja staatus on võimalik). Neil kõigil on erinevad õigused. Kujundaja vaates pannakse kursus kokku (materjalide viimine WebCT keskkonda, testide koostamine, üles- 
annete seadistamine, materjalide süstematiseerimine mooduliteks ja lisalehtedeks jms). Õpetaja vaade võimaldab kursust hallata - õppijate lubamine kursusele, rollide määramine, rühmade moodustamine, hindamistabelite täitmine, õppijatele materjalide kättesaadavaks muutmine või nende "peitmine" jms. Vana WebCT versioon andis kursuse läbiviijale, õpetajale vähem võimalusi kui uus. Ometi näib mulle, et uus versioon on tehniliselt küll mugavam, kuid õppijale (esmakasutajale) liiga keeruline, mistõttu kursuse alguses kulub keskkonnaga tutvumiseks palju rohkem aega kui vanas versioonis. Nii jääb mitugi head võimalust kasutamata, mis otseselt hinnet ei mõjuta, kuid oleksid siiski vajalikud. Näiteks visiitkaart (andmed kõikide õppijate kohta), meedia raamatukogud, sõnastik, näitematerjalid veebis jms.

Lisavahendid pakuvad fantaasiaküllaseid võimalusi, neid "kasvatatakse" tasapisi, mitme aasta vältel. See näitab, et kursused ei saa õigupoolest kunagi valmis, neid on võimalik täiendada, kujundada, muuta.

Kursuse põhiosa koosneb õppetekstidest, enesekontrolliharjutustest ja hinnatavatest ülesannetest, mis koondatakse teemade kaupa õpimoodulitesse. Iga mooduli läbimine on seotud kindla ajakavaga.

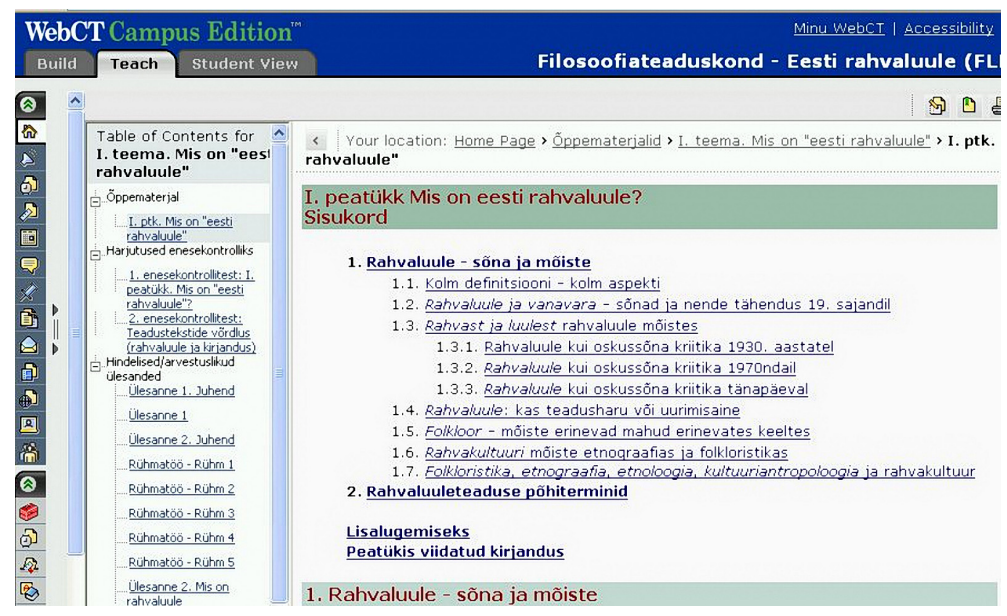

Joonis 4. Mooduli avaleht: ekraani kolmel väljal on vasakul WebCT menüü, järgmisel veerul mooduli sisukord ja suurel väljal avatud õppeteksti esileht.

Hindelisi ülesandeid on kolme laadi: testid, failide esitamine ja foorum. Kahte esimest kasutan individuaaltööks, foorumit aga ka rühmatööks. Enamasti on ülesandeks esitada loetud materjalidest kokkuvõte arutelufoorumile. Seal arutletakse kaasõppijatega foorumile saadetud postituste üle ja koostatakse arutelu kokkuvõte. Näiteks ülesanne "Eesti rahvaluule" kursuselt: 
Järgnevalt on esitatud kaks teksti:

1. rahvaluule kohta koostatud õpilasreferaat (URL 28.01.2004)

2. rahvaluuleüliõpilase kirjutatud ajaleheartikkel teemal, mis on rahvaluule, ajendatuna välitöödest (rahvaluule kogumisest): Moonika Siimets, Rahvaluule pole haua äärel, vaid elus ja terve. - Maaleht, 5.09.2002.

- Leia rahvaluule kohta käivad otsustused.

- Millised neist on üksteisele vastukäivad.

- Proovi leida põhjused, miks autor on valinud ühe või teise otsustuse (isiklik kogemus, teooria, rahvaluulealane kirjandus, ühiskondlikult käibivad arusaamad jms).

- Milliseid seisukohti ise pooldate ja miks.

Postita oma vastused oma rühma nimelisele foorumile. Sõnastage rühmaga rühmaarutelust neljast-viiest punktist koosnev kokkuvõte ja saatke see üldisele foorumile: Mis on rahvaluule.

Failide esitamine võimaldab õppijal koostada vastusfail oma arvutis ja saata see hindamiseks õppejõule. Vastusfaile on võimalik avaldada - st nähtavaks muuta kõigile kursusel osalejatele, ja selle vahendi abil on failide koostamist võimalik seadistada ka rühmatööks. Nii keerulisi vorme ma siiski seni veel kasutanud ei ole: kahtlen, kas üliõpilane, kes õieti tavalisel foorumilgi veel ei orienteeru, suudab vabalt mõelda oma ülesandele, kui tehniline pool hõivab kogu ta tähelepanu.

Foorumeid saab luua nii hindeliste ülesannete kui ka teadete, tagasiside ja lihtsalt suhtlemise jaoks. Rühmatöö vahendina olengi kasutanud kõige enam foorumit.

Teste kasutan meeleldi nii õppematerjalidest loetu kontrollimiseks (enesekontrolliks) kui ka kumuleeruvateks ülesanneteks (s.o esimene ülesanne valmistab ette järgmise lahendamist), nii internetist materjali otsimiseks (testi saab lisada uusi aknaid/lehti avavaid linke) kui ka lühianalüüside esitamiseks. Test võimaldab esitada nn täpseid vastuseid (nt leia sellelt või teiselt leheküljelt need või teised andmed ja kirjuta testi lahtrisse). Selliseid ülesandeid loon eesmärgiga suunata üliõpilasi e-publikatsioonide ja sealt täpsema informatsiooni leidmise juurde (ta peab lugema teksti, et leida õige vastus), kuid ühtlasi on see ka informatsioon käsitletava teema kohta (nt loomamuinasjuttude hulk väljaandes, tüüpide arv, muinasjutu tüübi number vms). Ka on võimalik rakendada selliseid teste näiteks laulu mikrokujundi analüüsis. Pikemate tekstide analüüsis saab aga kasutada vabade vastustega testi. Testivahend lubab koostajal esitada ka vastuse, mida õppija näeb (vastavalt sätetele) kas kohe pärast vastamist või pärast hindamist. Vastuste hindamisel ei saa loota masi- 
nale, kuid mulle sobib see omapoolse vastuse pakkumine testi juurde, sest nii saab õppija kohe tagasisidet - ta saab võrrelda oma vastust minu omaga. Hindamisel on aga mul omakorda hea, kui saan võrrelda ülesande koostamise ajal sõnastatud vastust õppija esitatuga, sest koos õppijaga ma enam ülesannet ju ei lahenda. Testi kontrollvastuste lahtrisse varem kirjutatud vastusele lisaks saan aga hindamise ajal kommenteerida õppija vastust ja põhjendada oma hinnangut tema tööle, mis võimaldab õppijal saada ka individuaalset tagasisidet. See on õppejõu seisukohalt loominguline protsess. Auditoorse töö kontrollivõimalused - tavaliselt kirjalik eksamitöö kursuse lõpus - ei võimalda mul kunagi anda õppijale nii põhjalikku tagasisidet, sest üldjuhul ei tulegi õppija oma vastust vaatama, piirdub hinde vaatamisega õppeinfosüsteemist. Ka ei jõuaks ma aja ega mälumahu poolest sõnastada eksamipäevade jooksul kirjalike tööde kohta detailset tagasisidet. WebCT-s esitatakse aga ülesanded perioodiliselt ning korraga nõutavate vastuste maht on väiksem kui kursuse lõpul esitatud töödel. Nii et kui õppijaga veebikeskkonnas koostöö laabub, on mul rohkem võimalusi anda talle tema töö kohta vastukaja. Enesekontrollitestidel, isegi kõige lihtsamatel juhtudel, kus on vastusvariandid: esitatud väide on õige / vale, saan ma esitada ka vastuse põhjenduse ja viite, missugustest oppetekstidest peaks selle kohta lugema.

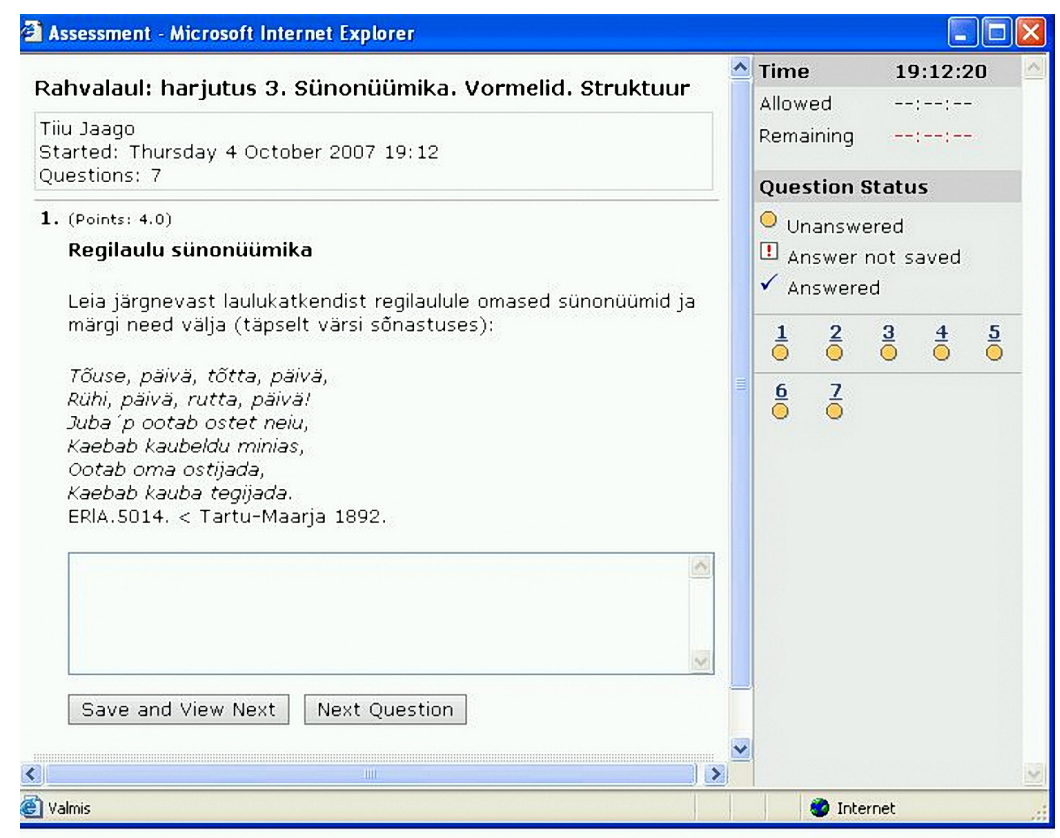

Joonis 5. Näide testist. 
Suhtlusvahenditest kasutan kõige enam foorumit, privaatseks suhtluseks meili. Kursuse vahenditest on muidugi otstarbekas kasutada ülesande iseloomule kõige paremini vastavaid, kuid samas ei tohiks ühel kursusel olla liiga erinevaid ülesande-keskkondi - see nõuaks õppijalt keskendumist tehnilistele asjadele, mis viib tähelepanu aine sisult mujale.

Hindamissüsteemi loomisel olen lähtunud põhimõttest, et erinevatel õppijatel oleksid kõigil oma võimalused saada paremat lõpptulemust. Selleks olen hindelised ülesanded jaotanud erinevate oskuste järgi, kus iga ülesanne annab teatud arvu punkte. Kursuse algusse ma kas ei plaani arvutitundmist nõudvaid ülesandeid (et anda aega õpikeskkonnaga harjumiseks) või pakun nimelt harjumiseks lihtsamaid (ka vähe punkte andvaid) ülesandeid. Individuaaltööd võivad olla testid ja vastusfailide koostamine ning oma sõnavõtu koostamine rühmaaruteluks. Sõnavõtte saab omakorda jaotada referaatideks (kui kokkuvõtte koostamise aluseks on teaduskirjandus), simulatsioonideks (kui ülesandeks on näiteks koostada ettekujuteldavas situatsioonis peetav kõne mingi etteantud seisukoha poolt või vastu) ja rollimängudeks (kus õppijad ei esita mitte enda seisukohti n-ö oma nahas olles, vaid valivad mingi rolli, kelle osa nad foorumil täidavad). Referaatide koostamine annab teadmiste baasi, mille najal saab luua simulatsiooni- ja rollimänge. Hindamisel saab aga jälgida, mil määral suudab õppija rakendada teadmisi simulatsioonimängus või mil määral ta tajub erinevate vaatepunktide võimalusi rollimängus. Õppija töö hindamise kõrval saab kasutada ka enesehindamist (mida ma siiski lõpphinde saamisega sidunud ei ole) ja kaasõppija hindamist (mida ma olen rakendanud, kuid hindan siis ka omakorda õppija oskust kaaslastele tagasisidet anda; seda olen rakendanud väiksemate uurimisplaanide koostamise juures, et kujundada teadustöös vajalikku väitlemisoskust, eriti aga oskust lähtuda töö analüüsis uurimisetapist ja kirjutaja taotlustest).

\section{Milliseid kogemusi on pakkunud kursuste läbiviimine}

Artikli alguses mainisin, et WebCT-kursused on minu silmis pigem argipäeva osa kui alternatiivne või tavalisest õppest eristuv töö. Erinevate õpetamiskeskkondade olemasolu on mulle andnud võimalusi paremini jaotada oma energiat, fantaasiat ja aega, kuna need keskkonnad toimivad erinevate rõhuasetustega. Loengutes tuleb pigem sisse elada käsitletava teema detailirikkusse, säilitades samas ABC-tasandit (sest üliõpilased kuulevad seda eeldatavasti esimest korda), ja samal ajal proovida leida endale mingi uus nüanss (sest muidu hakkab lihtsalt igav, kui loomingulist hetke ei teki). Samuti tuleb auditoorse töö puhul valmis olla täpselt siis, kui loeng või seminar on välja kuulutatud. 
Veebikursused ei eelda valmisolekut kindlal kellaajal ega nõua ka ABC värskeks mõtlemist. Töö WebCT-s on pigem tsükliline kui regulaarselt samatasandiline (väga intensiivne periood on kuus umbes korra, mis vaheldub kursust jälgiva perioodiga). WebCT-kursustel on väga oluline julgustada ja inspireerida õppijaid tööle. Tuleb pidevalt jälgida nende sõnavõtte, leida sealt need tahud, mis aine omandamise seisukohalt on viljakad edasiarenduseks. Kui loenguid võib lugeda suurele hulgale üliõpilastele, siis WebCT-kursus ei võimalda ühel õppejõul võtta liiga suurt kursust (minu jaoks on piir 20 üliõpilase ringis). Kuna WebCT-kursuste ülesanded ja hindamissüsteem ei ole otseselt üles ehitatud õppetükkidest pärit teadmiste kontrollile, vaid eeldab nende teadmiste üle arutlemist, kogemuste vahetamist ja edasiarendust, sõltub kursuse õnnestumine suuremal määral õppijatest kui õppejõust. Näiteks “Dialoogi” kursust olen läbi viinud kolmel korral. Esimesel ja kolmandal korral olid arutelud aktiivsed ja kursuslased pigem rahul, teisel aastal oli aga osalemine kuidagi leige, et mitte öelda igav. Avatud ülikooli "Folkloristika aluste" kursust on olnud kaks korda. Esimesel korral olid taas õppijad aktiivsed ja tagasiside peegeldas nende rahulolu. Näiteks:

Sain kursuselt harjutuste lahendamise käigus palju häid ideid, kuidas võimalusel muuta õpitund õpilastele mõistete kinnistamisel huvitavamaks. Eriti tänulik olen kursusel viidatud internetilehekülgede aadresside üle, need annavad võimaluse viia õppetund iseseisva tööna läbi arvutiklassis.

Väga positiivne oli kokku puutuda täielikult internetile ülesehitatud õppimisviisiga. Kui auditoorse õppetöö pooldajad toovad põhjenduseks, et peab / saab tekkida side õppejõuga, siis see kursus võimaldas tagasisidet ja vahetut suhtlemist hoopiski enam.

2007. aastal oli aga sama õpikeskkond kursus noorematele õppijatele võõras ja kohati pigem vastumeelne. Neist tagasiside lausetest kumab läbi palju rohkem arusaamatust kui eelmisel toimumisel.

Piisavalt edasi mõtlemist kursus ei võimaldanud, aga see on seetõttu, et rühmaarutelu oli vähe, kuna meil oli vähe aega (üks kord me jäime hiljaks ja teine kord ka kõik ei tulnud õigeks päevaks foorumisse). Aga sellegi poolest oli kursus pigem avatud, natuke iseseisvat mõtlemist ta ikkagi võimaldas.

Rühmatöökogemus jäi kasinaks, õigemini selle teostus pisut hämaraks. Rühmatöö eeldanuks, et me arutame teemat kusagil mujal, aga välja kukkus nii, et lihtsalt vastasime foorumis üksteise kirjadele. Arusaamatuks jäi see, miks neid chat roome'e nii palju on, piisaks vaid sellest, kui oleks üks ruum, kuhu kõik automaatselt sisse logides satuksid. 
WebCT õpe on ennast kindlasti õigustanud, muidu teda ei kasutataks eri ülikoolides ja usun, et selline õppimismeetod võidab kiiresti populaarsust. Keegi on öelnud, et Õpetaja saab õpilasele õpetada ainult suhtumist ainesse. Kummalisel kombel on õppejõu suhtumine ainesse tuntav ka ilma fü̈̈silise kohalolekuta, samamoodi mõjutavad meid ka kindlasti head raamatud, muusika, kunst jne. Mina kartsin väga, kuidas hakkama saan enne selle kursuse algust, siiani oleks nagu kerge värin sees aja peale tehtavate testide osas, siis tuli ka näpukaid õige rohkelt sisse. Ühenduse saamine online's oli probleemiks. Ettepanekuks oleks helina kasutamine, kui keegi sind chat'i kutsub. Lugemisse süvenenult lihtsalt ei märka seda hetke. Suhtlemine rühmatöös oleks ehk võimalik ka skype i kaudu. Meeldis väga see, et iga materjali osa lõppes testiga, et lõpuks teenitud hinne kätte saada. Aegajalt tekkis minulgi selline tunne, et ei saa materjalist aru, aga siis tuli ikka end tekstist "läbi närida”. Lõpetuseks ütleksin, et minu arusaam rahvaluulest on totaalselt muutunud. Palju sain linke, mida ka edaspidi kavatsen lugeda ning ka teistele soovitada.

Tagasiside võib olla üsna üllatav: kui mulle tundub, et kursus "läks käima” ja õnnestus, vähemalt pakkus mulle suurt huvi ja olin tänulik õppijatele, kes kursuse nii sisuliseks muutsid, siis vastulausetes ilmnes ükskõiksus või rahulolematus. Ja vastupidi, kus mulle tundus, et kursus mingil põhjusel ei töötanud täiskäigul, sain vastukajaks positiivseid kokkuvõtteid.

Miks tagasiside on oluline? Esmalt suunan ma õppija alati teda ennast analüüsima. Kursuse alguses palun tal sõnastada ootused kursuse ja aine suhtes. Kursuse lõpus: mis neist ootustest täitus, mis mitte. Edasi suunan teda analüüsima, miks ootused ei täitunud, küsides, milliseid vahendeid, lehekülgi jm võimalusi ta õppimisel kasutas, mida pidas endale oluliseks ja mis jäid kõrvale. Seega: miks tema õppeprotsess ja tulemused kujunesid just selliseks, nagu need kursuse lõpuks olid. Õppija eneseanalüüs peaks andma talle endale teadmise oma õpimeetoditest, sellest, mis talle paremini sobivad, kuidas end ise motiveerida ja distsiplineerida. Seega - avastada ennast, milline õppija ta on.

Minu silmis õnnestub kursus siis, kui tekivad küsimused. Näiteks 2007. aasta sügissemestri õpetajakoolituse kursusel oli esimeseks ülesandeks koostada võrdlev tabel rahvaluule definitsioonidest, mida nad ise otsisid kas netist või (kooli)õpikutest (definitsioonid, allikad, milles seisneb definitsioonide sarnasus ja erinevus ning millest need erinevused võivad tulla). Definitsioone otsiti tõesti innukalt ja tabelid täideti hoolikalt. Erinevusi defineerimisel aga ei nähtud kusagil. Siin tuli natukene üliõpilasi küsimustega ärritada ja suunata uuesti õppematerjale lugema. Tabelitena esitatud informatsioon oli aluseks aruteluks rühmatöö foorumil. Püstitasin küsimuse: kuidas nemad ise kooli- 
tunnis sõnastaksid selle, mis on rahvaluule, ja millest nad lähtuksid. Varsti ilmusidki õppijate sisulised küsimused. Näiteks:

Kas rahvaluule eelduseks on kultuuriline kokkukuuluvus? Kui vaadelda Honko ja Dundesi definitsioone, siis Honko eeldab seda, sest sotsiaalse identiteedi all võiks justkui mõelda rahvast. Aga Dundes oma artiklis ürtleb selgelt: "Rahvas on mis tahes sotsiaalne rühm, kuhu kuulub vähemalt kaks inimest.” Kas siis ei saakski rääkida ühe rahva oma rahvaluulest ühe kultuuri kontekstis? Kas igal rahvusel on oma kultuurikontekstis oma rahvaluule? Kas nt islamiusulisel ja õigeusulisel on kristliku eestlasega ühes kollektiivses rühmas elades üks rahvaluule? See on üks kitsas näiteküsimus, ma tegelikult ei defineeri kultuuri ainult religiooniga $: D$

Minu meelest on 7. klassi (Nahkur; Sokk) kirjandusõpiku lähenemine väga poolik... "Rahvaluule on eestlaste pärimusliku vaimse kultuuri see osa, mille moodustab poeetiline sõnalooming /... / "Arusaadav, et lastele selgitatakse asja kirjandusõpikus kirjanduse vaatepunktist, kuid kui mõelda, et "rahvaluule” mõistet käsitletaksegi õppekava järgi vaid kirjanduse tunnis, siis oleks vaja ikkagi asja laiemalt vaadelda. Sealt tulebki lapsel arusaam, et rahvaluule on midagi vana ja mitte praegu kasutusel olev. Mis teised arvavad?

Kui eeldada, et netinaljad ja grafitid on rahvaluule, siis kas ka need on väärtuste vundamendid? Kui jah, siis millistele väärtustele need alustala panevad? (Viide viimasena postitatud definitsioonide tööle.)

Nii tuleb iga õppija kursusele oma pagasiga ja asi ei piirdu ka minu puhul kaugeltki sellega, mida ma enne kursust juba tean. Õppijate sõnavõtud võimaldavad näha, kust ja kuidas nad informatsiooni otsivad, millistest seisukohtadest nad materjale lugedes n-ö üle loevad, mida nad ei märka, mille üle nad ei mõtle, sest asi tundub selge olevat.

\section{Kokkuvõtvalt}

Kursuse koostaja ja läbiviijana on mul võimalik hallata faile (õppetekstid; näitetekstid; kujunduselemendid), kursuse ülesehitust, ülesandeid; õppijatega seonduvat. Aastate jooksul on mul välja kujunenud oma stiil nii kursuse ülesehitamise, lisavahendite kasutamise kui ka õppemeetodite valimisel. Eelistan probleemõpet ja seni olen eelistanud ka täielikku veebikursust (mitte kombineeritud kursusi). Et õppijate ring on hakanud muutuma - õppijate erinev suhtumi- 
ne näiteks kohustuslikesse ja valik- või vabaainetesse -, sunnib see mind enam mõtlema kombineeritud õppevormidele. WebCT-kursuste loomine on olnud väga intensiivne periood, kohati närvesöövalt väsitav (kursuse liiga lühike ettevalmistusaeg, tehnikaalane asjatundmatus, kursuste ülekandmine uude versiooni). Ometi on see andnud mulle võimaluse mõelda enam õppemeetoditele, mu enda õppimisele ja sellest tulenevale õpetamiseelistustele. See on andnud võimaluse kohtuda selliste erialade õppejõududega ja kursustega, kellega / millega ma muidu oma töös iialgi kohtunud poleks. See on andnud võimaluse siduda õppetöö enam selle tööga, mida on tehtud kirjandusmuuseumis e-andmebaaside ja e-publikatsioonide loomisel: need materjalid ei ole pelgalt illustratsiooniks loengus/seminaris, vaid neis sisalduvad võimalused on inspireerinud koostama ülesandeid. Siinkohal suur tänu kõigile, kelle töö kaudselt kajastub e-kursustes, eriti aga kaastööd teinutele, kelleks on: Mare Kõiva, Liisa Vesik (Dialoog privaatse ja avaliku elu vahel); Piret Voolaid, Mall Hiiemäe (Eesti rahvaluule); Liina Saarlo (Regilaulu uurimise meetodid), Liisi Laineste ja veel kord Piret Voolaid (Teksti- ja kontekstikesksed meetodid folkloristikas). Eriline tänu minu kannatlikele koolitajatele haridustehnoloogidele Lehti Pildile ja Marju Piirile ning paljuski inspiratsiooni andjale Karin Ruulile. Ja nagu ikka: ilma õppijateta ei ärka siiski sellest tööst ellu õieti midagi.

\section{Kommentaarid}

${ }^{1}$ Vt nt Tartu Ülikooli eesti ja võrdleva rahvaluule osakonna kodulehelt http:// www.folklore.ee/UTfolkl/loengud/index.html; Tiiu Jaago loetavate kursuste kodulehelt http://lepo.it.da.ut.ee/ tjaago

${ }^{2}$ Vt WebCT-kursuste nimekirja Eesti E-Ülikooli WebCT kodulehelt: http://webct.euni.ee.

${ }^{3}$ Vt kursuse tutvustust raamprogrammi "Regionaalselt kättesaadav kvaliteetne kõrgharidus läbi e-õppe arenduse” (REDEL) aruandes http://portaal.e-uni.ee/redel/alamprojektid/sisutootmine/2005/TiiuJaago.pdf/view

${ }^{4}$ Vt kursuse tutvustust raamprogrammi "Regionaalselt kättesaadav kvaliteetne kõrgharidus läbi e-õppe arenduse" (REDEL) aruandes: http://portaal.e-uni.ee/redel/alamprojektid/sisutootmine/2006/TiiuJaago.pdf/view

5 Vt probleemõppe tutvustust nt Hakkarainen \& Lonka 2005.

${ }^{6}$ Kursuse ettevalmistuse ja ülesehituse põhimõtetest olen kirjutanud pikemalt eõppe võimalusi käsitleva teoreetilise peatüki lisana raamatus "Õppimine ja õpetamine avatud ülikoolis" (Jaago 2005a). Kursus osales 2004. aastal Eesti e-ülikooli korraldatud aasta e-kursuse konkursil ning sai põhjaliku, professionaalse ja algupärase õppematerjali preemia.

7 Kursuste ettevalmistuse kohta vt nt teooriat Pilli 2005, Ruul 2005 ja kogemusi Veebel 2005, Jaago 2005b. 
8 Kursuste loend on aadressil http://webct.e-uni.ee > Course List. Kui valida Eesti e-Ülikool > Demokursused, siis on võimalik ühte kursust ("Filosoofia põhiprobleemid") näha ka tervikuna - 5.oktoober 2007.)

\section{Kirjandus}

Hakkarainen, Kai \& Lonka, Kirsti 2005. Probleemipõhine õppimine. Larissa Jõgi, Tiia Ristolainen (koost). Oppimine ja õpetamine avatud ülikoolis. Tartu Ülikooli Kirjastus, lk 262-272.

Jaago, Tiiu 2005a. Veebipõhise kursuse rakendamisest Tartu Ülikoolis eesti rahvaluule kursuse näitel. Larissa Jõgi, Tiia Ristolainen (koost). Õppimine ja õpetamine avatud ülikoolis. Tartu Ülikooli Kirjastus, lk 378-379.

Jaago, Tiiu 2005b. Rahvaluule käsitlemise võimalusi õppetöös kolme kursuse näitel. Larissa Jõgi, Tiia Ristolainen (koost). Õppimine ja õpetamine avatud ülikoolis. Tartu Ülikooli Kirjastus, lk 238-241.

Pilli, Einike 2005. Õppetegevuse planeerimine ja ainekursuse ettevalmistamine. Larissa Jõgi, Tiia Ristolainen (koost). Õppimine ja õpetamine avatud ülikoolis. Tartu Ülikooli Kirjastus, lk 218-225.

Pilt, Lehti \& Läheb, Reelika 2005. E-õpe täiskasvanud õppijale: kuidas üles ehitada e-kursust. Larissa Jõgi, Tiia Ristolainen (koost). Õppimine ja õpetamine avatud ülikoolis. Tartu Ülikooli Kirjastus, lk 344-377.

Ruul, Karin 2005. Kuidas sõnastada õpieesmärke? Larissa Jõgi, Tiia Ristolainen (koost). Õppimine ja õpetamine avatud ülikoolis. Tartu Ülikooli Kirjastus, lk 226-227.

Veebel, Viljar 2005. Koolituskursuse ettevalmistamine Tartu Ülikooli Euroopa kolledži näitel. Larissa Jõgi, Tiia Ristolainen (koost). Õppimine ja õpetamine avatud ülikoolis. Tartu Ülikooli Kirjastus, lk 228-237.

\section{Summary}

\section{Online Folklore Courses: From Curiosity to Experience}

Tiiu Jaago

Key words: tertiary education, e-learning, virtual learning environment, WebCT, folklore teaching methods

There are three types of online folklore courses available at the University of Tartu: epublications of open access study materials (subject web sites, e-lectures, and e-textbooks), video lectures (e.g., on DVD), virtual e-learning environment with limited access (three main e-learning platforms are used in Estonia: WebCT, Moodle, IVA). In this article I focus on my eight years of experience with WebCT, having worked as a learner, course compiler (including designer) as well as the lecturer. 
The need for web-based courses increased together with the growth and the broadened opportunities in the use of WWW. The fact that the web site of Estonian Folklore (www.folklore.ee) already featured a number of electronic databases as well as e-publications introduced the need for the use of these materials in educational work. WebCT enables the user to present material in written and audio format, present lore texts as audio or video recordings or images and thus present web lore in an entirely natural context. Present-day students have grown up in the computer era, which is why searching the Web for material is as natural to them as searching for information in books once was.

At the stage of familiarising myself with WebCT (2000-2002) I put together course materials while the web materials were technologically integrated by Lehti Pilt, education technologist at the University of Tartu. In 2003-2004, I acquired skills of preparing a WebCT course (formulate the subject, determine the e-course structure, consider learning assignments and methods, the use of WebCT devices, etc.) and by 2006 I had developed skills of designing the course, taking part in courses and seminars, compiling courses and carrying these out. This was an active process of acquiring new information which consummated with the introduction of the new version of WebCT in 2006, which for me was a serious setback: I had to do extra technical work at converting the courses from the old version of WebCT to the new one. Regardless of that, WebCT has turned into an equal (though not alternative) work environment to conventional learning (traditional classroom sessions). This, however, is not a common apprehension: students who are not comfortable with computer communication are sure to mention it in formal feedback, while the opposite version (of students officially protesting against traditional learning) is very rare indeed. In informal feedback, however, preferences and objections of both types of learning are proportional. On the one hand, it seems that at its present stage, the students and the general public of the university has accepted the use of WebCT (or other interactive learning environments). This learning environment is nothing extraordinarily new or novel and people are readily willing to join these courses. Many have their own experiences and have formed prejudices. On the other hand, it is not exactly the case in actual discourse: people speak about WebCT as an alternative type of learning, the creation of web-based courses are not perceived as something that a lecturer has to be skilled in, course participants dare to object to the choice of virtual environment (which would not be possible in terms of traditional classroom learning, as this might lead to the question of why they had entered the university in the first place). 